\title{
Fishes associated with spinner dolphins at Fernando de Noronha Archipelago, tropical Western Atlantic: an update and overview
}

\author{
Ivan Sazima*, Cristina Sazima* and José Martins da Silva-Jr**
}

\begin{abstract}
An update is presented for fish species associated with spinner dolphins at Fernando de Noronha Archipelago, tropical Western Atlantic, providing a general view of their diversity. The associates are mostly reef-dwelling fishes that feed on the dolphin wastes. Twelve species are habitual or occasional plankton-eaters and two species are herbivores that occasionally forage on floating pieces of algae. One species is a strict carnivore, one species is a hitchhiker that forages on a variety of foods including parasites and dead tissue from the dolphins, and one species is a carnivore that joins the dolphin groups to forage on schools of small fishes or squids. We predict that the list of fish associated with spinner dolphins will expand mostly with addition of habitual or occasional plankton-eaters.
\end{abstract}

Uma atualização é apresentada sobre as espécies de peixes associados a golfinhos-rotadores no Arquipélago de Fernando de Noronha, Atlântico Ocidental, fornecendo uma visão geral sobre sua diversidade. Os peixes associados são principalmente habitantes recifais que se alimentam de dejetos dos golfinhos. Doze espécies são planctófagas habituais ou ocasionais e duas são herbívoras que se alimentam ocasionalmente de algas à deriva. Uma espécie é carnívora estrita, uma vive fixada aos golfinhos e seu alimento é variado, incluindo parasitos e tecido morto dos golfinhos, e uma é carnívora que se junta aos grupos de golfinhos durante a caça a peixes e lulas. Prevemos que a lista de peixes associados a golfinhos-rotadores seja expandida principalmente com adição de planctófagos habituais ou ocasionais.

Key words: Fish-cetacean symbiosis, Foraging groups, Feeding modes, Plankton-eaters.

\section{Introduction}

Until recently five fish species were reported in association with spinner dolphins (Stenella longirostris, Delphinidae): the remora Remora australis (Echeneidae), the tuna Thunnus albacares (Scombridae), the jack Caranx latus (Carangidae), the damselfish Abudefduf saxatilis (Pomacentridae), and the triggerfish Melichthys niger (Balistidae). The remora or whalesucker is recorded attached to cetaceans only (review in O'Toole, 2002); the tuna is known to join hunting groups of dolphins to prey on the same schooling fishes and squids (Perrin et al., 1973; Silva-Jr. et al. 1996); the three remainder species forage on dolphins' feces (Lodi \& Fiori, 1987; Lodi 1998). The last feeding habit is reported only from Fernando de Noronha Archipelago, off Brazil, tropical Western Atlantic. In the last five years, underwater studies on fishes associated with spinner dolphins increased three- fold the list of species known to feed on dolphins' feces, besides adding vomits as a food source for these fishes (Sazima et al., 2003). Moreover, details of the association of whalesuckers with spinner dolphins were reported recently (Silva-Jr. \& Sazima, 2003, 2006; Silva-Jr. et al., 2005).

We present here an update and an overview of fishes associated with spinner dolphins at Fernando de Noronha Archipelago. The associates are grouped by two distinct features, the main foraging mode (e.g., roving carnivore) and the role in the association (e.g., waste-eater). What we call here an association may either be an intimate and long-lasting contact with a dolphin (e.g., hitch-hiking remoras, Silva-Jr. \& Sazima, 2003, 2006) or a fleeting approach to the dolphin groups to feed quickly on wastes (several species, see Sazima et al., 2003). Based on this information, we make generalizations and predictions on the associations between fishes and spinner dolphins.

\footnotetext{
* Departamento de Zoologia e Museu de História Natural, Caixa Postal 6109, Universidade Estadual de Campinas, 13083-970 Campinas, São Paulo, Brazil.e-mail: isazima@unicamp.br

**Centro Golfinho Rotador, Caixa Postal 49, 53990-000 Fernando de Noronha, Pernambuco, Brazil.
} 


\section{Material and Methods}

Underwater observations while snorkeling among spinner dolphins were carried out at Fernando de Noronha Archipelago (0350'S, $\left.32^{\circ} 25^{\prime} \mathrm{W}\right)$, off Northeastern Brazil, tropical Western Atlantic (see Maida and Ferreira, 1997 and Sazima et al., 2006 for map and description). Observational sessions were carried out mostly at the Dolphins' Bay, a 15-25 m deep inlet with an area of about $3 \mathrm{~km}^{2}$, although observations at other sites of the archipelago were made as well, including the dolphins' open-water feeding grounds (Silva-Jr. et al., 1996, 2005). Records were taken from June 1998 to October 2006 in a total of 243 diving days and about $208 \mathrm{~h}$ underwater. Data was gathered mostly during studies focused on fish behaviors while associated with dolphins (e.g., Sazima et al., 2003; Silva-Jr. \& Sazima, 2006), but occasional observations made during studies focused on spinner dolphin behaviors (e.g., Silva-Jr. et al., 2004, 2005) were used as well. We relied on "ad libitum" and "behavior" sampling rules (Martin \& Bateson, 1986), in which all behaviors displayed by fishes associated with dolphins were recorded, however short-lasting could be the association. Besides records on plastic slates, the fishes and their behavior were photographed and/ or video-taped. We discarded any doubtful record, e.g., that of sharks that joined dolphins in their foraging groups, of which we were unable to ascertain identity beyond family level (Carcharhinidae). Voucher samples of photos and videorecording are on file at the quarters of the Centro Golfinho Rotador at Fernando de Noronha Island, and in the Museu de História Natural da Universidade Estadual de Campinas
(ZUEC). Voucher specimens of Harengula jaguana and Melichthys niger are in the fish ZUEC collection (access numbers 6305 and 5349 respectively).

\section{Results}

Seventeen fish species are presently known to associate with spinner dolphins at Fernando de Noronha Archipelago, most of them being plankton-eaters that feed on dolphins' feces and/or vomits (Table 1). Morphology varies widely (Fig. 1) due to the diversity of fish families comprised in this assemblage. Herrings (Clupeidae) and scads (Carangidae) bear a vague resemblance to each other due mostly to their openwater and planktivorous habits. The same applies, albeit to a lesser extent, to the pelagic and predaceous tunas (Scombridae) and jacks (Carangidae). The latter family has the largest number of species associated with dolphins (five), followed by Pomacentridae and Balistidae (two each), the remainder associates being scattered over eight families.

Five individuals from a small school of about 100 scaled sardines (Harengula jaguana) were recorded once feeding on spinner dolphins' feces over sandy bottom in front of a small harbor, Porto de Santo Antonio, where these cetaceans lingered for a while on the way to their feeding grounds. This clupeid gathers in large schools (Fig. 1b) over sandy beaches to feed on zooplankton around Fernando de Noronha Archipelago. The black jack (Caranx lugubris), moving single (Fig. 1d) or in pairs, was recorded four times feeding on dolphins' feces in the calm bay where the dolphins rest and socialize, the Dolphin's Bay. This carangid may be seen in several habi-

Table 1. Fish species recorded in association with spinner dolphins (Stenella longirostris) at Fernando de Noronha Archipelago. Arrangement of families follows Nelson (1994) except for Hemiramphidae (= Exocoetidae); species in alphabetical order.

\begin{tabular}{|c|c|c|}
\hline Fish species & Main foraging mode & Main role in the association \\
\hline \multicolumn{3}{|l|}{ Clupeidae } \\
\hline Harengula jaguana & particle-forager & waste-feeding \\
\hline \multicolumn{3}{|l|}{ Hemiramphidae } \\
\hline Hemiramphus brasiliensis & particle-forager & waste-feeding \\
\hline \multicolumn{3}{|l|}{ Echeneidae } \\
\hline Remora australis & particle-forager, cleaner & hitch-hiking, waste-feeding \\
\hline \multicolumn{3}{|l|}{ Carangidae } \\
\hline Caranx bartholomaei & roving carnivore & waste-feeding \\
\hline Caranx crysos & roving carnivore & waste-feeding \\
\hline Caranx latus & roving carnivore & waste-feeding \\
\hline Caranx lugubris & roving carnivore & waste-feeding \\
\hline Decapterus macarellus & particle-forager & waste-feeding \\
\hline \multicolumn{3}{|l|}{ Lutjanidae } \\
\hline Lutjanus јоси & sedentary carnivore & waste-feeding \\
\hline \multicolumn{3}{|l|}{ Kyphosidae } \\
\hline Kyphosus sectatrix & browser, particle-forager & waste-feeding \\
\hline \multicolumn{3}{|l|}{ Pomacentridae } \\
\hline Abudefduf saxatilis & particle-forager, browser & waste-feeding \\
\hline Chromis multilineata & particle-forager & waste-feeding \\
\hline \multicolumn{3}{|l|}{ Labridae } \\
\hline Clepticus brasiliensis & particle-forager & waste-feeding \\
\hline \multicolumn{3}{|l|}{ Acanthuridae } \\
\hline Acanthurus coeruleus & browser, particle-forager & waste-feeding \\
\hline \multicolumn{3}{|l|}{ Scombridae } \\
\hline Thunnus albacares & roving carnivore & group-hunting \\
\hline \multicolumn{3}{|l|}{ Balistidae } \\
\hline $\begin{array}{l}\text { Canthidermis sufflamen } \\
\text { Melichthys niger }\end{array}$ & $\begin{array}{l}\text { particle-forager } \\
\text { particle-forager, browser }\end{array}$ & $\begin{array}{l}\text { waste-feeding } \\
\text { waste-feeding }\end{array}$ \\
\hline
\end{tabular}


tats around the island, from calm bays to drop-offs with currents. One dog snapper (Lutjanus jocu) individual was recorded feeding on a dolphin's vomit in the water column once in the Dolphin's Bay. This lutjanid was recorded mostly sheltered in the reef at daytime. A small group of three Brazilian wrasses (Clepticus brasiliensis) was recorded feeding on

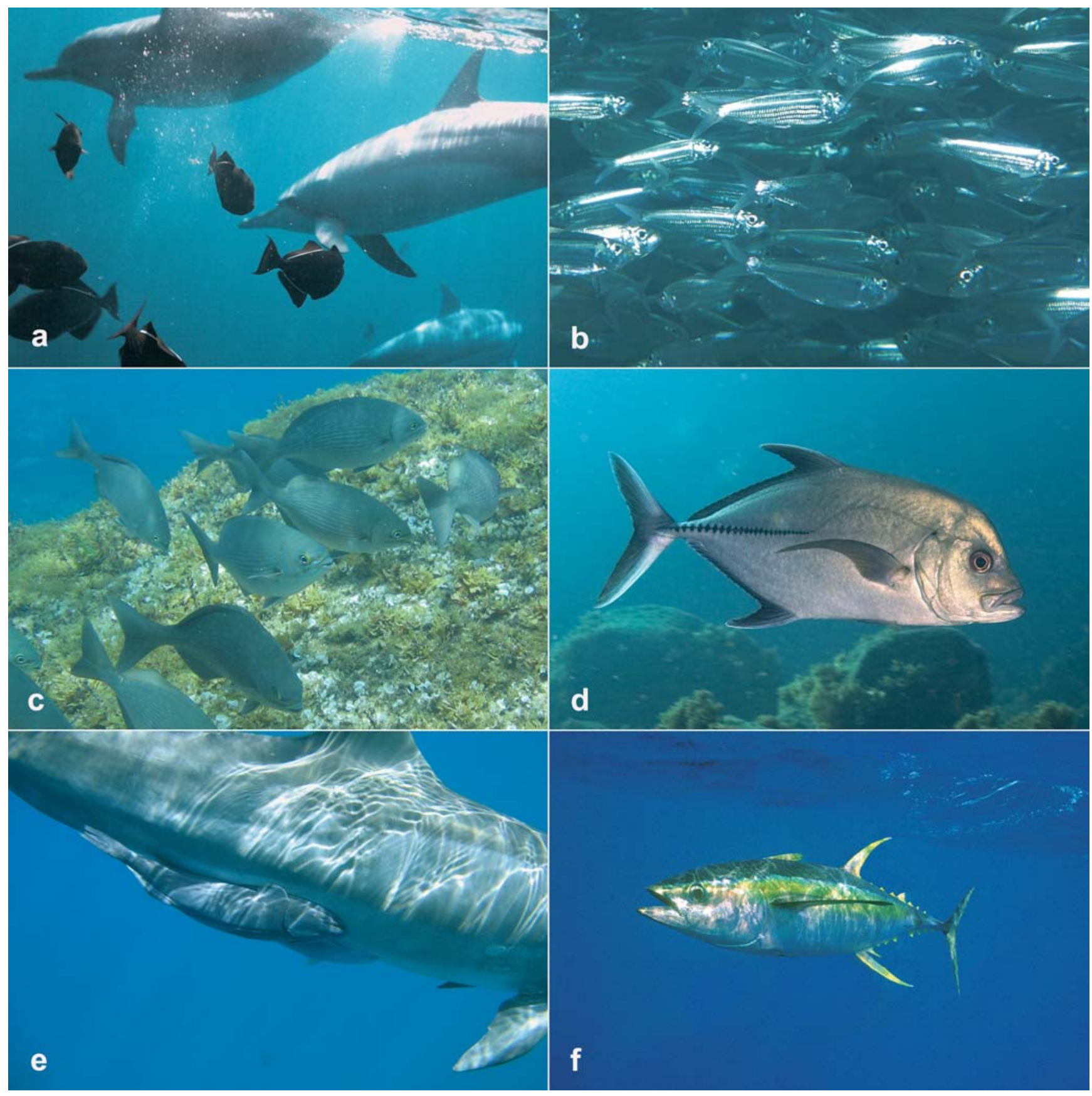

Fig. 1. Six selected fish species recorded in association with spinner dolphins (Stenella longirostris) at Fernando de Noronha Archipelago. Black durgon (Melichthys niger), a particle-forager and browser that feeds on dolphin wastes habitually in the Dolphins' Bay (a). Photo by I. Sazima. Scaled sardine (Harengula jaguana), a particle-forager that feeds on dolphin wastes occasionally while the dolphins cruise close to sandy beaches (b). Photo by C. Sazima. Bermuda chub (Kyphosus sectatrix), a browser and particle-forager that feeds on dolphin wastes occasionally in the Dolphins' Bay (c). Photo by C. Sazima. Black jack (Caranx lugubris), a roving carnivore that feeds on dolphin wastes occasionally in the Dolphins' Bay (d). Photo by J. P. Krajewski. Whalesucker (Remora australis), a hitch-hiker on cetaceans that forages on spinner dolphin wastes and cleans them of parasites and dead tissue (e). Photo by J. M. Silva Jr. Yellowfin tuna (Thunnus albacares), a roving carnivore that joins spinner dolphins while the latter forage for schooling fish and squids in their hunting grounds around the archipelago (f). Photo by G. Marcovaldi (Banco de Imagens Projeto TAMAR-IBAMA). 
dolphins' feces once in the calm Dolphin's Bay, which is surprising as this labrid dwells at edges of drop-offs with currents to feed on zooplankton. Number of records and other data on the remainder fish species associated with spinner dolphins at Fernando de Noronha Archipelago are in Sazima et al. (2003). Further information on the habits of these fish species is in Humann (1996) and Carvalho-Filho (1999).

Most fish species associated with the spinner dolphins are particulate-eaters or browsers (Table 1, Fig. 1) that dwell in several types of reef habitats, from calm and shallow ones to areas with strong currents or swell. Exceptions are the jacks of the genus Caranx, roving carnivores able to use varied hunting tactics (see below), and the dog snapper ( $L$. $j o c u$ ), a nocturnal zoobenthivore and piscivore. The fish most intimately associated with the spinner dolphins is the whalesucker (Remora australis), a hitchhiker and cleaner on these cetaceans (Fig. 1e). The yellowfin tuna (Thunnus albacares) is the only roving carnivore positively recorded to associate with groups of spinner dolphins hunting at afternoon and dusk. This pelagic fish (Fig. 1f) was never seen near the reefs.

\section{Discussion}

Most species associated with spinner dolphins are reefdwellers or at least near-shore inhabitants (Sazima et al., 2003), the exceptions being the pelagic Decapterus macarellus, Canthidermis sufflamen, and Thunnus albacares (the two former approach reefs occasionally, see Humann, 1996; Carvalho-Filho, 1999). This trend may reflect our record bias towards reefs and near-shore habitats, as well as our inability to observe the spinner dolphins while on their pelagic hunting grounds around the archipelago (Silva-Jr. et al., 1996) with the exception of T. albacares records. On the other hand, spinner dolphins defecate and vomit mostly while resting and interacting in the Dolphins' Bay, a reef habitat (Sazima et al., 2003; Silva-Jr. et al., 2005) and, thus, the waste-eaters that comprise most of the fish species associated to dolphins are expected to be reef-dwellers.

Three of the present additions to the list of 12 species recorded in a study of fishes feeding on dolphins' wastes (Sazima et al., 2003) deserve brief remarks. One such species is Clepticus brasiliensis, uncommon elsewhere and a dweller of reef drop-offs where it forages in the water column (Carvalho-Filho, 1999; our pers. obs.) herein recorded once in a calm bay. An unexpected addition is Harengula jaguana, however common its large schools may be on shallow sandy beaches around the island. Its association with spinner dolphins likely occurs only when these latter leave the resting sites and move to their hunting grounds (Silva-Jr. et al., 1996). This latter record strengthens the view that our observations on fishes associated with dolphins are biased towards these cetaceans' resting sites referred to above. Another unexpected addition is the dog snapper (Lutjanus jocu), a sedentary piscivore and zoobenthivore that hunts mostly at night (e.g., Starck and Davis, 1966; Randall, 1967). In the archipelago we recorded this snapper occasionally foraging near its reef shelters at daytime, the larger individuals in the open and darting at schools of scaled sardines (H. jaguana).

Not surprisingly, jacks (Carangidae) are the fish group best represented among the spinner associates. Carangids are renowned for their variable foraging repertoire that includes chase, ambush, disturbance of substrate to uncover hidden prey, following of substrate-disturbing zoobenthivores, and particulate-feeding (e.g., Sancho, 2000; Sazima et al., 2003; Sazima et al., 2006). Four out of the five Caranx species reported for Fernando de Noronha Archipelago (Soto, 2001) are now recorded to associate with spinner dolphins to feed occasionally on wastes (however, records of $C$. hippos for the archipelago are doubtful, W. F. Smith-Vaniz, pers. comm.). Of these, C. bartholomaei is the species that displays the most variable foraging tactics, whereas the three remainder species are more or less bound to their roving predaceous tactics and occasional particulate-feeding (e.g., Sazima, 1986; Sazima et al., 2003; Sazima et al., 2006).

The sergeant major (Abudefduf saxatilis) is a very versatile forager as well, but relies mostly on plankton-picking in the water column, or browsing on the reef substrate and sometimes on marine turtles (Randall, 1967; Carvalho-Filho, 1999; Sazima et al., 2004; Grossmann et al., in press). Catholic foraging may also apply to the black durgon (Melichthys niger) (Carvalho-Filho, 1999; Sazima et al., 2003).

The whalesucker-dolphin association is usually regarded as an instance of phoresis or hitch-hiking. The attachment of the same remora individual to the same dolphin host may last about three months, possibly more (Silva-Jr. \& Sazima, 2003). Cleaning and other foraging types are involved in this symbiosis as well. Remora australis forages on the host's wastes, cleans the host on occasions, and ram-feeds on particulate food while attached to the moving host (Silva-Jr. et al., 2005; Silva-Jr. \& Sazima, 2006).

Based on the presently known assemblage of fishes associated with spinner dolphins and their main foraging habits we predict that the list of associate species will expand a little further, and that most of the additions will be either reef-dwelling or pelagic planktivores that feed on dolphin wastes occasionally. One expected addition while the dolphins move over reef pinnacles or in shallow water near reefs would be the Noronha wrasse (Thalassoma noronhanum, Labridae), a versatile forager recorded to feed on fish feces (Sazima et al., 2005). Another addition while the dolphins move to their feeding grounds would be the bigeye scad (Selar crumenophthalmus, Carangidae), a pelagic forager on zooplankton (Froese \& Pauly, 2006) recorded around Fernando de Noronha Archipelago (Lessa et al., 1998; IS, pers. obs.).

\section{Acknowledgements}

We thank J. P. Krajewski and G. Marcovaldi for kindly allowing use of their photographic records; PETROBRAS, 
AVINA, Instituto Vivo, CNPq, and FAPESP for essential financial support; the IBAMA for issuing permits to study spinner dolphins and reef fishes in the Marine National Park of Fernando de Noronha, and for logistic support.

\section{Literature Cited}

Carvalho-Filho, A. 1999. Peixes: costa brasileira. São Paulo, Melro, $304 \mathrm{p}$.

Froese, R \& D. Pauly. 2006. FishBase. World Wide Web electronic publication. www.fishbase.org.

Grossman, A., C. Sazima, C. Bellini \& I. Sazima. (in press). Cleaning symbiosis between hawksbill turtles and reef fishes at Fernando de Noronha Archipelago, off Northeast Brazil. Chelonian Conservation and Biology, 6.

Humann, P. 1996. Reef fish identification: Florida, Caribbean, Bahamas. Jacksonville, New World, 396 p.

Lessa, R., L. Sales, M. R. Coimbra, D. Guedes \& T. Vasque-Jr. 1998. Análise dos desembarques da pesca de Fernando de Noronha (Brasil). Arquivos de Ciências do Mar, 31: 47-56.

Lodi, L. 1998. Comensalismo entre peixes recifais do Arquipélago de Fernando de Noronha e golfinhos-rotadores, Stenella longirostris. Biotemas, 11: 127-132.

Lodi, L. \& B. Fiori. 1987. Observações sobre o comportamento do golfinho-rotador; Stenella longirostris (Cetacea, Delphinidae) na Ilha de Fernando de Noronha - Brasil. Anais da 2a Reunião de Trabalho de Especialistas em Mamíferos Aquáticos da América do Sul, Rio de Janeiro, Brasil: 60-68.

Maida, M. \& B. P. Ferreira. 1997. Coral reefs of Brazil: an overview. Proceedings of the $8^{\text {th }}$ International Coral Reef Symposium, Panama, 8: 263-274.

Martin, P. \& P. Bateson. 1986. Measuring behaviour, an introductory guide. Cambridge, Cambridge University, $200 \mathrm{p}$.

Nelson, J. S. 1994. Fishes of the world. $3^{\text {rd }}$ ed. New York, John Wiley \& Sons, $600 \mathrm{p}$.

O'Toole, B. 2002. Phylogeny of the species of the superfamily Echeneoidea (Perciformes: Carangoidei: Echeneidae, Rachycentridae, and Coryphaenidae), with an interpretation of echeneid hitchhiking behaviour. Canadian Journal of Zoology, 80: 596-623.

Perrin, W. F., R. R. Warner, C. H. Fiscus \& D. B. Holts. 1973. Stomach contents of porpoise, Stenella spp., and yellowfin tuna, Thunnus albacares, in mixed species aggregations. Fishery Bulletin, 71: 1077-1092.
Randall, J. E. 1967. Food habits of reef fishes of the West Indies. Studies in Tropical Oceanography, 5: 665-847.

Sancho, G. 2000. Predatory behaviors of Caranx melampygus (Carangidae) on spawning fishes: a novel ambushing strategy. Bulletin of Marine Science, 66: 487-496.

Sazima, C., A. Grossman, C. Bellini \& I. Sazima. 2004. The moving gardens: reef fishes grazing, cleaning, and following green turtles. Cybium, 28:47-53.

Sazima, C., R. M. Bonaldo, J. P Krajewski \& I. Sazima. 2005. The Noronha wrasse: a "jack-of-all-trades" follower. Aqua Journal of Ichthyology and Aquatic Biology 9:97-108.

Sazima C., J. P. Krajewski, R. M. Bonaldo \& I. Sazima. 2006. Nuclear-follower associations of reef fishes and other animals at an oceanic archipelago. Environmental Biology of Fishes, DOI 10.1007/s10641-006-9123-3.

Sazima, I. 1986. Similarities in feeding behaviour between some marine and freshwater fishes in two tropical communities. Journal of Fish Biology, 29: 53-65.

Sazima, I., C. Sazima \& J. M. Silva-Jr. 2003. The cetacean offal connection: feces and vomits of spinner dolphins as a food source for reef fishes. Bulletin of Marine Science, 72: 151-160.

Starck, W. A. \& W. P. Davis. 1966. Night habits of fishes of Alligator Reef, Florida. Ichthyologica, 38: 313-356.

Silva-Jr., J. M., L. J. Pandolfo \& I. Sazima. 2004. Vomiting behavior of the spinner dolphin (Stenella longirostris) and squid meals. Aquatic Mammals, 30: 271-274.

Silva-Jr., J. M. \& I. Sazima. 2003. Whalesuckers and a spinner dolphin bonded for weeks: does host fidelity pay off? Biota Neotropica, 3: 1-5.

Silva-Jr., J. M. \& I. Sazima. 2006. Whalesuckers on spinner dolphins: an underwater view. JMBA2-Biodiversity Records: 1-6. http:/ /www.mba.ac.uk/jmba/jmba2biodiversityrecords.php

Silva-Jr., J. M., F. J. L. Silva \& J. A. Pereira. 1996. O comportamento do golfinho rotador em F. de Noronha. Anais do $14^{\circ}$ Encontro Anual de Etologia, Uberlândia, MG, Brasil: 251-262.

Silva-Jr., J. M., F. J. L. Silva \& I. Sazima. 2005. Rest, nurture, sex, release, and play: diurnal underwater behaviour of the spinner dolphin at Fernando de Noronha Archipelago, SW Atlantic. Aqua Journal of Ichthyology and Aquatic Biology, 9: 161-176.

Soto, J. M. R. 2001. Peixes do Arquipélago Fernando de Noronha. Mare Magnum, 1:147-169.
Submitted September 2006 Accepted November 2006 